\title{
Fog Computing and its Impact on Business Environment Analytical Capabilities In Light of Crises and Disasters
}

\section{Abdullah Mohammad Ali Almazroie, Khaled Abdel Kader alomari}

To Link this Article: http://dx.doi.org/10.6007/IJARBSS/v10-i12/8319

DOI:10.6007/IJARBSS/v10-i12/8319

Received: 13 October 2020, Revised: 12 November 2020, Accepted: 29 November 2020

Published Online: 18 December 2020

In-Text Citation: (Almazroie \& Omari, 2020)

To Cite this Article: Almazroie, A. M. A., \& Omari, K. A. A. A. (2020). Fog Computing and its Impact on Business Environment Analytical Capabilities In Light of Crises and Disasters. International Journal of Academic Research in Business and Social Sciences, 10(12), 323-340.

Copyright: (c) 2020 The Author(s)

Published by Human Resource Management Academic Research Society (www.hrmars.com)

This article is published under the Creative Commons Attribution (CC BY 4.0) license. Anyone may reproduce, distribute, translate and create derivative works of this article (for both commercial and non-commercial purposes), subject to full attribution to the original publication and authors. The full terms of this license may be seen at: http://creativecommons.org/licences/by/4.0/legalcode

Vol. 10, No. 12, 2020, Pg. 323 - 340

Full Terms \& Conditions of access and use can be found at http://hrmars.com/index.php/pages/detail/publication-ethics 


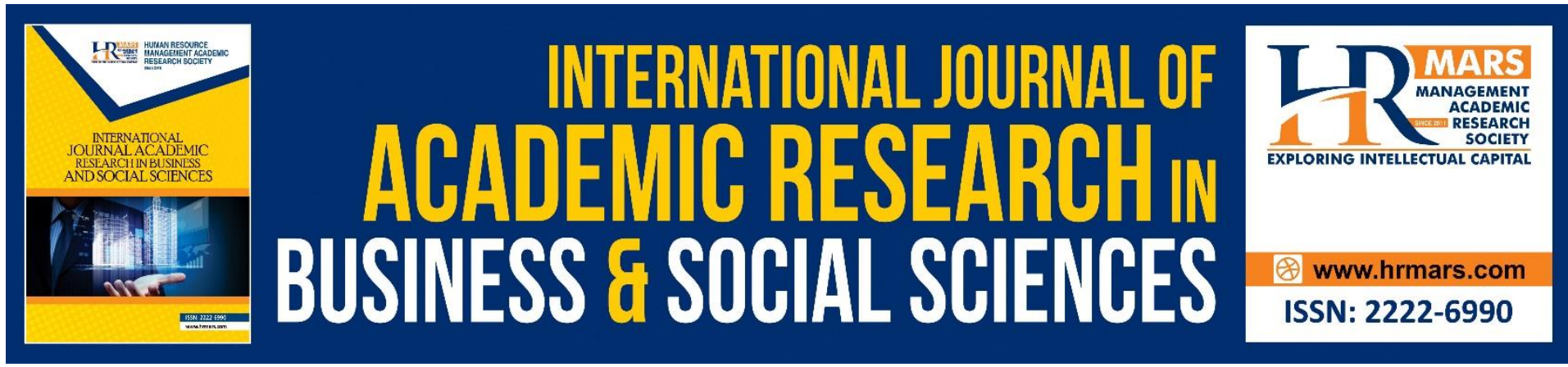

\title{
Fog Computing and its Impact on Business Environment Analytical Capabilities In Light of Crises and Disasters
}

\author{
Abdullah Mohammad Ali Almazroie, Dr. Khaled Abd Alqader Al- \\ Omari
}

Department of Business Administration -Business Collage- JADARA University, Jordan

\begin{abstract}
The study is aimed at identifying "Foggy computing and its impact on the analytical capabilities of the business environment in light of crises and disasters." The researcher may use the descriptive analytical approach to suit his nature of the study. Therefore, and to achieve the goals, a questionnaire study tool was developed for this purpose. In addition, the study community included all the national bodies for emergency management of crises and disasters in the United Arab Emirates, which numbered (750) employees. The sample study consisted of (224) employees and the results of the study were as follows; There was an effect of the system quality, information quality, and quality of services on simulation, meanwhile, there was no effect of user satisfaction on simulation.

In addition, there was an effect on the following areas: system quality, information quality, and quality of service on analytical quantitative modeling, meanwhile, there was no effect for the fourth field: user satisfaction on analytical quantitative modeling.

In conclusion and in light of the results, the researcher made several recommendations, the most important of which are: Supporting various business enterprises to practice their activities in an integrated manner within fog or fog computing and activating them to manage business and its uses well in light of the surprises that the business is experiencing at the environmental level
\end{abstract}

Keywords: Fog Computing, Analytical Capabilities, Simulation, Analytical Quantitative Modeling, Business Environment, Crises and Disasters

\section{Introduction}

The recent advances made in the field of information technology and the emergence of the phenomenon of globalization and convergence in the field of industry constitute challenges for organizations to remain as much as possible in severe competitive environments, where the organizations need to understand the importance of performance as a component that can help them increase profit, achieve sustainable growth, and identify new ways of interacting with customers. (Aljawarneh et al, 2020), as it is assumed that it should lead to assisting institutions and bodies in discovering innovative business models to improve so as to increase operations, facilitate customer participation and increase their 
levels of satisfaction, which is supposed to lead to improved performance, service delivery, increased sales, as well as increased loyalty of clients (Shana \& Abulibdeh, 2017). Therefore, fog computing is considered as one of the most appropriate technologies, which can help organizations to obtain a strategic advantage in a competitive environment, where this era is referred to as the age of knowledge (Obeidat, 2019), because organizations are experiencing a lot of dynamism and challenges in business environments, and due to the fact that the relevant change and development is an integral part of the present world (Madhavaiah, Bashir, \& Shafi, 2012). Today, organizations are permanently affected by environmental factors that can lead to failure or success, and in this field, organizations tend to use this technology to adapt to the various environmental factors that require application growth, rapid processing, dynamic access and reducing costs, which drives organizations to expand its scope to reach massive capacity without the need to invest in new infrastructure or hire new employees. Therefore, this is considered as one of the most appropriate technologies, which provide a common set of technology resources ranging from devices, applications and storage networks which can be obtained by organizations upon request. (Bidgoli, 2011; malkawi et al, 2017) More importantly, these resources can be rapidly expanded or reduced as required by organizations and it offers the latest online fog-based applications that can be obtained by agents and supervisors in real time to be integrated with the existing enterprise systems such as ERP system, supply chain management system, or customer relationship management, to provide complete information to the company on sales, marketing, customers as well as the financial position in order to enhance business values and gain strategic advantage (Stanoevska, et al, 2009).

Based on the above, the study aims at identifying fog computing and its impact on the analytical capabilities of the business environment. This is due to the fact that organizations seek and work for the future by conducting proactive evaluation processes for possible scenarios and relying on them in decision-making, which basically need accurate and rigorous methods and approaches such as simulation and analytical quantitative models. Based on this, fog computing has been dealt with as an independent variable in its dimensions (System quality, information quality, service quality, user satisfaction). Meanwhile, analytical capabilities have been dealt with in its dimensions (Simulation, analytical quantitative modeling).

Therefore, success requires organizations to keep abreast of everything new in the world of management, and to increase their ability to obtain knowledge in the correct form that contributes to continuity and excellence, and, hence, ensures access to advanced positions in competition and creativity (Paul \& Muthumani, 2015; Obeidat, \& Otibi, 2015 ). Besides, this requires them to follow successful methods in order to help them in improving its activities and upgrading the level of its services to ensure its ability to compete (Kocaoglu \& Acar, 2015). In addition, the organizations need data and information resources that can help them define criteria for clearly and accurately assess their performance in light of competition markets. Accordingly, the relevant capabilities to analyze the business environment is considered as one of the most important issues that still require research and attention at all levels because it reflects the status of the organization, its progress and achievement, especially in light of the variables such as globalization, intensity of competition and tremendous technological developments (Yousefpour et al., 2019), which forces organizations to consider technology as an investment as one of the solutions to improve performance through the capabilities of the analysis of the business environment (Javadzadeh $\&$ Rahmani, 2020). Hence, the researcher decided to conduct a field study on the National 
Emergency and Crisis and Disaster Management Authority in the Emirates, which may be considered as one of the first organizations in the world that employed fog computing to manage the entity entrusted with managing crises, disasters and emergencies in light of the first integrated electronic government in the Middle East as far as the researcher's knowledge. Consequently, it shall assume the need to continue to keep pace with the developments of fog computing systems by integrating the capabilities of artificial intelligence present in fog computing to create an effective system that works with huge capabilities which combine artificial intelligence with huge storage capabilities, and hence providing great capabilities in managing workflow procedures and controlling procedures by sharing the data and information between the various sectors in which the authority plays a monitoring role to monitor violations and abuses in violation of the various regulations, instructions and laws in the UAE, with the aim of its continuation and increasing efficiency in its performance in light of any economic, social, political or other crisis in order to assist it in various decisiontaking and decision-making processes due to the accuracy, difficulty and complexity of their work in unusual circumstances constantly. From this point, the systems that may cause a change in increasing the capabilities of business analysis are fog computing systems, according to the researcher's opinion, because the authority had previously experimented with fog computing applications that had not helped in analyzing the various works which the authority carries out in a relevant manner and the required accuracy. Therefore, it replaced it with a fog computing system, which our study hopes to reach whether this application is compatible with the desired goal by carrying out the analyzes process of the various work of the authority in order to assist the decision-making process.

\section{Fog Computing}

Fog computing was established and derived by Cisco Systems in early 2012 as a bridge between fog computing and customers. This new computing paradigm was initially advanced to extend the cloud to the corporate network edge to provide computing and resources closer to the user than the cloud, in addition to the wider geographical distribution. Moreover, it has been beneficial to reduce the connection load to fog computing required to increase the efficiency and security. It is worth mentioning that fog computing has addressed some fog issues, such as latency to data, lack of navigation support, and site awareness (Al Yami \& Schaefer, 2019; Darwish\& Abdeldayem, 2019). Foggy computing perfectly illustrates the concept of a distributed network environment that connects two different environments together and linked to fog computing and the Internet of things (Bonomi, et. al., 2012). Meanwhile, (Vaquero, 2014) defined it as an extension of fog computing which is a virtual platform for the purpose of gathering resources that provide services of network storage for close end users to facilitate for them to reach their destination.

Such computing worked in data centers as a decentralized model, i. e. it does not require the infrastructure in the computational centers of the data centers, which helps users to accomplish their tasks easily without complication (Dastjerdi et al., 2016), so that the storage space is rounded up to the users, which leads to reduced response time if compared to communicating with fog servers. Also, it provides local processing facilities for reduced data volume, high throughput and lower latency (Barik et. al, 2018). For the development and implementation of a fog computing model, fog devices have been used, i. e. hardware fog, which is computers that include, Raspberry $\mathrm{Pi}$ and Intel Edison that are used as a gateway to both end users and the cloud. Besides, to implement reliable fog architecture, it requires a scalable, efficient and fog-dependent GIS architecture for analyzing and segmenting large 
geospatial data. The fog computing model is considered as one of the new ideas that helps reduce the quantity and increase the productivity of the users (Barik et al., 2017), so that fog engineering can solve the geospatial problem by keeping geospatial data closer to local devices instead of directing through centralized data server in the cloud (Fiduccia et al., 2017).

Fog computing is considered as one of the technological concepts closely related to the development of systems that are used in various administrative applications and works to develop businesses to implement them efficiently and effectively, along with the dimensions of fog computing which consist of the following elements:

\section{- System Quality}

System quality is defined as the systems, policies, and interactive relationships that are structured; to achieve the goals, and tasks of the organization. In addition, system quality has been defined as the plan that the organization works on under stable environmental conditions, or under unstable conditions. Therefore, system quality may contribute in the improvement and development of the general performance, enhancing the production process, and achieving the objectives targeted by the organization. (Agbim, 2013; Irtaimeh et al, 2016). Furthermore, system quality is considered as an integrated, interconnected chain of inputs, systems, and outputs that is followed by the feedback for the purpose of continuous and tireless improvement. The quality of the system includes the adoption of values, principles, and instructions; in order to control the trends and behaviors of its employees, as the organization's distinction lies through its achievement and maintenance of superior performance levels that meet and exceed the needs and expectations of all concerned stakeholders, and a good system is the means by which the flow of business and coordination between the departmental divisions of the organization, the chain of command, and the channels of communication within it (Tran \& Tian, 2013). Hence, the quality of the system may be reflected in the productivity by showing concern for achieving the needs of the employees, and the environment, whether internal or external, surrounding the organization, any may affect the development of employee skills to create a better service for the organization, by finding out problems and interacting with customers faster (Latifi \& Shooshtarian, 2014; Shrouf et al, 2020).

\section{- Information Quality}

The studies related to the quality of information are characterized by scarcity and focus on the characteristics of qualitative information. Such studies attempted to define the dimensions that are based on it and the most important of them are (Internal subjective quality, contextual quality, presentation and presentation, and accessibility) which are considered as a basis for evaluating the extent of the added value of internal and external information (Duran -Arenas et al, 1998), and was classified into more comprehensive classifications, some of which were closely related to time in terms of timing and the extent of its novelty, and others related to the content such as comprehensiveness, accuracy, clarity and flexibility (Brien, 2008). Therefore, the quality of information is determined by the way it is used by the decision maker towards its effect on him by standing before a specific decision, and its ability to make the decision-maker reach effective decisions that serve the goals of the organization. The quality and strength of information emerges through three main factors: Hassan (2008) which is the extent of usefulness of such information to the decision-maker, the extent of satisfaction with the information and the percentage of mistakes and bias. 
Hence, information quality is considered as a critical factor for the success of information system services, where Chin (2012) refers to the extent of its impact on the success of the information system, and he proposed a model that displays four main dimensions of the quality of information provided to the information system, including: communication, information content, interaction, and the context of information content.

\section{- Service Quality}

Service quality is defined as those dimensions, which mainly aim at achieving customer satisfaction by working on the development of high-quality services provided to customers; besides, it is referred to as being able to follow up between the requirements, perceptions, and needs of customers, and the level of services provided to them by organizations (Nejad et al., 2014). Therefore, the importance of such quality lies in the extent to which the services provided to customers match their requirements and perceptions, as customers have special standards and preconceptions about the various services provided by the organization, which requires service organizations to take into account these needs and desires, and devote its time, effort, human and material resources; to reach the major goal, which is achieving customer satisfaction, retaining them, and continuing to provide them with appropriate services that meet their needs. Hence, success is achieved by comparing customers to services, preferring one service to others due to its distinction and achieving satisfaction for customers, which is a condition for achieving competitive goals and surpassing other institutions in the labor market (Ramachandran \& Chidambaram, 2012). The material and moral of the products or services, the extent to which the service conforms to the requirements, perceptions, and needs of the customers, and reliability, especially as this dimension constitutes the level of customer dependence on the organization in providing the best quality of services or products at a low cost and a high speed in the correct manner, which would contribute to retaining customers and achieving their satisfaction followed by the response that is the readiness, willingness of workers, and employees in the organization to provide services to customers, and honesty in the organization's dealings with customers so that it puts customer satisfaction in its priority and provides customers' interest over all competitive and profitable interests and others. Meanwhile, as for sympathy, it is defined as showing the organization interests, and the desire to provide the best services and products to customers, then, reliability, which means the credibility of the service provider, which is the organization, and how well it adheres to its promises to customers to gain their trust (Quyet et al., 2015).

\section{- User satisfaction}

User satisfaction is considered as one of the most ambiguous concepts in the managerial psychology, as it is difficult to measure due to its association with feeling and sense, especially as it is related to the psychological feelings of the user towards his work. In addition, it is a group of feelings that may be positive if the user is satisfied when his moral and material needs are satisfied, and those feelings set towards the user's experience of using the system. (Kamal \& Baharudin, 2013; Mahafzah et al, 2020) defines user satisfaction as the extent to which the user can benefit from the system and the ability of the system to help the user reach what he seeks (Al-Mahamid, 2012). However, and despite what the service organizations face from sever competition among each other, still the availability of positive satisfaction among its users and the extent of its development of the systems and the ease of use makes it an opportunity to distinguish it more competitively than other organizations, as 
it gains employees' loyalty through the services provided to them and the extent to which those services meet their needs (Kotler \& Keller, 2012). Therefore, customer's satisfaction is considered as one of the important features that contribute to the evaluation and distinction of the organization, especially in light of the advanced modern technology, which has entered every organization from its widest doors to keep pace with the time of globalization, and hence enables it to obtain the advantage Sustainable (Conklin, et., Al, 2004; Alomari et al, 2020).

\section{The Analytical Capabilities of the Business Environment}

In the last century, the world has witnessed a great development in the field of technology and communications, which has widely allowed information tools to interfere in the administrative development that is the basic building block for building the organization, as the administrative process began to grow clearly through the decisions it takes to achieve goals, especially with the launch of technological development and communication which contributed to changing the views of the administrative levels in most matters along with their speed in making those decisions and their contribution to the challenge of the competitive environment, whether internal in solving problems or external in facing problems and seizing available opportunities (Haidar, 2006). Therefore, the organizations always strive for success, progress and achieving competitive advantage in the long term by improving its distinctive productive capabilities and services provided through highly qualified human resources and technological infrastructure, and maintaining their continuous development (Hall, 1993; Al-qudah et al, 2020). Accordingly, the capabilities of all kinds, especially technological ones, are among the most important internal resources of the organization, which is characterized by excellence and a high competitive reputation among its customers, as the positive relationship between each one of the technological capabilities and organization's environmental in terms of its performance and its distinction (Navas, 2007). In addition, these capabilities also benefit the administrative performance through (Ahmed, 2015): Optimal utilization of resources, and its primary role in setting the organization's longterm plans and maintaining a larger market share and higher competitiveness, and interaction with various processes in the work environment, which gains strength and increases its competitiveness.

Therefore, the use of the analytical tools in the business environment is considered the essence of the administrative process, as their use optimally increases the accuracy of the analysis results and ensures a somewhat balanced methodology. Besides, the analytical tools in the business environment are very important that we cannot abandon as they work on analyzing both the internal and external environments of the organization which determines the threatening it faces from the competitive confrontations, and hence makes it ready for the same. (Wright et. al., 2013). Furthermore, the tools of organizational analysis are defined as those methods, practices, methods and methodologies followed by the organization in the decision-making support process Voloshina (2014), as well as the frameworks that the decision makers put it in order to achieve accuracy in the results of the analysis, and, thus, make the decision that serves the achievement of the desired goals. Consequently a number of researchers indicated in their study to the importance of using analytical tools in the business environment in terms of presenting information in ways that increase the awareness of the decision maker and limit the problems that may face the organization due to this decision (Frost, 2003). From the viewpoint of the researcher Knott (2006), the role and importance of the analytical tools lies in supporting creativity and innovation, that is to say 
producing knowledge as well as supporting the participation of individuals and groups (Mahfodh \& Obeidat, 2020; Saffar, \& Obeidat, 2020 ). Especially since the environmental analysis tools in the business environment are divided into several types including: Pestel analysis, SWAT analysis, Porter's five forces analysis, and McKinsey framework analysis. Hence, these tools have become the main pillar that drives the administrative business environment (Tassabehji \& Isherwood, 2014).

The effective analytical capabilities are represented by the extent of the organization's ability to collect the data we need to solve the problems it may face, and how to use such data in the work environment in an unrealistic way that simulates the real work environment without compromising its parts through mathematical models and symbols. The following is a statement of the dimensions of the analytical capabilities of the business environment:

\section{- Simulation}

Simulation is a symbolic arrangement of the system that is based on the use of a set of mathematical models which study the behavior of the said system during a certain time; and, in another concept, it is the attempt to reach a work environment similar to the real environment but without affecting it (Abdul Karim, 2018). On the other hand, Adnan (2002) defined it as a set of possibilities in the form of mathematical or symbolic relationships within the system, so that the work of the system is used in order to test the said system and the extent of the impact of the relevant changes and interactions that may result from these mathematical relations if applied to practical reality. Meanwhile, Bari (2007) defined simulation as the imitation of features of a real physical system using mathematical relationships and adopting its basic idea in a manner that does not affect the performance. Hence, the importance of simulation models lies in the fact that they are one of the most effective and efficient mathematical models due to their ease of use in the event of many hypotheses, where the decision-maker gains new experiences in facing the problems that they may encounter in different situations, by identifying the potential long-term threats and trying to avoid them through finding permanent alternative solutions. In addition, this model gives an opportunity for the organization to do many experiments, and, thus, the organization avoids the actual or potential risks as it returns to the traditional mathematical procedures in solving more complex models (Hamdan, 2010).

\section{- Analytical Quantitive Modeling}

Management in the organization adopts analytical quantitative modeling methods in decision-making processes in order to support it while trying to find alternatives to the problem it faces and to indicate the extent of its impact on the organizational performance. Accordingly, analysis is two types; either quality analysis that cares for the external and personal side of the director, i.e. his expertise and experiments, meanwhile, quantative analysis which depends on the actual quantative facts for the data and its relationship with the problem in question. (Anderson et al., 2006). Anderson defined those models as the processes that are used to solve problems and make the right decisions based on scientific methods. Meanwhile, analytical quantitative models are defined as those methods and procedures that follow models and equations based on solving the problems logically and realistically (Najm, 2001; Alomari, 2020). Besides, Al-Fadl (2006) also saw that these models are an expression of the set of scientific methods used to solve problems and support taking the appropriate administrative decision. But, this requires the availability of the vast amount of data on which the solution to the problem is based, as well as the availability of hypotheses 
and the alternative hypotheses and what are the factors affecting the administrative decision, whether direct or indirect factors. Al-Hiti (2000) added that they are the supporting models that are used in the analysis of problems for decision-making in the form of mathematical equations and interactions, thus, reaching the results and applying them in practice.

Accordingly, the importance of the quantitative modeling is represented by the fact that it helps solving administrative problems by bringing them closer to reality and formulating such problems with the symbols and mathematical relationships that reflect the reality of the administrative problem, developing the relevant alternative hypotheses and choosing the most appropriate one after testing it along with the system's ability to use these models in the future if the organization faces a similar problem. Thus, the analytical quantitative modeling helps the business environment in the decision-making process, being able to: (Bilal, 2005) represent the problem on the ground and developing different alternatives to solve problems by presenting them in a mathematical model represented by a set of mathematical relationships as well as the ability of the administration to apply and use this model in the future, if faced with the same problems, besides the ability of modeling to quickly solve complex problems along with its ability to examine the solution and its attempt to change the conditions in proportion to the alternative hypotheses.

\section{Study Approach}

This study is an applied study which works on solving field problems and developing work productivity in administrative fields. Therefore, the study adopts the descriptive method that aims at describing certain phenomena or events, collecting facts and information about them, describing their conditions and determining their status as they are in reality. It is also concerned with determining the phenomena or events that the research deals with in light of certain values or standards, and suggesting steps or methods that can be followed to reach the picture that it should be in light of these standards or values.

\section{Study Hypotheses}

This study came with two assumptions:

- There is a statistically significant effect of fog computing in its dimensions (System quality, information quality, service quality, and user satisfaction) in the simulation.

- There is a statistically significant effect of fog computing in its dimensions (System quality, information quality, service quality, and user satisfaction) on analytical quantitative modeling.

\section{Population and Sample Study}

The community of the study included all employees of the National Emergency Crisis and Disaster Management Authority in the United Arab Emirates, whose number reached (750) employees. Sekaran statistical tables were relied upon to determine the size of the acceptable sample, as it was turned out that the size of the acceptable sample at the level of confidence (95\%) is (255) single (Sekaran \& Bougie, 2010). Therefore, (255) questionnaires were distributed to a sample chosen randomly from the Authority's employees, and the number of retrieved questionnaires reached (235), out of which (11) were not valid for statistical analysis, because they were not completed. Consequently, the number of recovered and statistically analyzable questionnaires reached (224), meaning (87.8\%) of the total distributed questionnaires, which is a statistically acceptable percentage. Table No. (1) Shows the characteristics of the sample. 
Table (1) Demographic data for responde

\begin{tabular}{|c|c|c|c|}
\hline Variable & Category & Repetition & Percentage \\
\hline \multirow{3}{*}{ Gender } & Male & 124 & 55.4 \\
\hline & Female & 100 & 44.6 \\
\hline & Total & 224 & 100 \\
\hline \multirow{5}{*}{ Age } & Less than $\mathbf{3 0}$ years & 65 & 29.1 \\
\hline & $\begin{array}{c}30 \text { - less than } 40 \\
\text { years }\end{array}$ & 85 & 37.9 \\
\hline & $\begin{array}{c}\text { 40- Less than } 50 \\
\text { years }\end{array}$ & 57 & 25.4 \\
\hline & 50 years and over & 17 & 7.6 \\
\hline & Total & 24 & $\% 100$ \\
\hline \multirow{5}{*}{$\begin{array}{l}\text { Educational } \\
\text { Qualification }\end{array}$} & Secondary & 16 & 1.7 \\
\hline & Diploma & 17 & 7.6 \\
\hline & Bachelor & 167 & 74.6 \\
\hline & Postgraduate & 24 & 10.7 \\
\hline & Secondary & 224 & 100 \\
\hline \multirow{5}{*}{ Experience } & Less than 5 years & 81 & 36.2 \\
\hline & $\begin{array}{c}\text { 5-less than } 10 \\
\text { years }\end{array}$ & 60 & 26.8 \\
\hline & $\begin{array}{c}\text { 10-less than } 15 \\
\text { years }\end{array}$ & 67 & 29.9 \\
\hline & 15 years and over & 16 & 7.1 \\
\hline & Total & 224 & $\% 100$ \\
\hline \multirow{4}{*}{ Position } & Director & 13 & 5.8 \\
\hline & $\begin{array}{l}\text { Head of the } \\
\text { Department }\end{array}$ & 36 & 16.1 \\
\hline & Employee & 175 & 78.1 \\
\hline & Total & 224 & $\% 100$ \\
\hline
\end{tabular}

\section{Test Validity and Reliability of the Study Tool}

The validity of the study tool was verified after presenting it to a group of experienced arbitrators in the practical and academic fields, along with their comments and suggestions about the questionnaire which were taken into account in terms of the adequacy of the study tool, its clarity, correlation, coherence, and the extent to which the questions match the desired variables. Moreover, the process of auditing and reviewing the questionnaire by the arbitrators and taking their observations, and making the amendments referred to by them, was considered as a test of the apparent validity of the tool, and accordingly, the study tool was considered suitable for measuring what it was designed for. The reliability of the tool used in measuring its components (Dimensions) were tested by using Cronbach Alpha Coefficient test, where the result of the scale is statistically acceptable if the value of Cronbach Alpha is greater than $(0.60)$ (Sekaran, 2006, 311). The closer the value to $(100 \%)$, this indicates higher degrees of stability for the study tool. In view of the data contained in the following table, the internal consistency coefficient of Cronbach Alpha was measured for the study variables and their dimensions, as well as for the study tool as a whole, to see the extent of consistency in the answers as follows: 
Table (2) Value of the reliability coefficient (Kern Bach alpha) for the metrics and metrics fields as a whole

\begin{tabular}{|c|c|c|c|}
\hline Field & $\begin{array}{c}\text { Cronbach's } \\
\text { Alpha Value }\end{array}$ & Field & $\begin{array}{c}\text { Cronbach's } \\
\text { Alpha Value }\end{array}$ \\
\hline System quality & 0.807 & Simulation & 0.806 \\
\hline Information quality & 0.739 & $\begin{array}{c}\text { Analytic quantitative } \\
\text { modeling }\end{array}$ & 0.824 \\
\hline Service quality & 0.778 & $\begin{array}{c}\text { A measure of the } \\
\text { analytical capabilities } \\
\text { of the business } \\
\text { environment as a } \\
\text { whole }\end{array}$ & 0.897 \\
\hline Fog computing scale as a \\
whole
\end{tabular}

It can be seen from Table (2) above that the values of the reliability coefficients for the metric fields ranged from (0.739-0.826), and its value for the fog computing scale was (0.938) and for the analytical capabilities scale of the business environment (0.897), all of which are high enough values for the purposes of the study.

\section{Descriptive Statistics}

This part of the study reviews the description of the study variables. Arithmetic averages of the study variables have been calculated for the purpose of judging the degree of approval and determining the relative importance of each variable.

Table (3): The results of analyzing the responses of the sample members for the fog computing items

\begin{tabular}{|c|c|c|c|c|}
\hline No. & Dimension & $\begin{array}{c}\text { Arithmetic } \\
\text { Average }\end{array}$ & Rank & $\begin{array}{c}\text { Relative } \\
\text { importance }\end{array}$ \\
\hline 1 & System quality & 3.749 & 4 & High \\
\hline & Information quality & 3.783 & 3 & High \\
\hline 2 & Service quality & 3.797 & 2 & High \\
\hline 3 & User satisfaction & 3.825 & 1 & High \\
\hline \multicolumn{2}{|r|}{ Fog computing scale as a whole } & $\mathbf{3 . 7 4 9}$ & & High \\
\hline
\end{tabular}

The results of Table (3) above indicate that the level of fog computing in terms of relative importance is high, as the arithmetic mean reached (3.759), and the table also showed that the dimension of (user satisfaction came first with an average of (3.825) and of high relative importance, while it came after (quality System) ranked last with an average (3.749), and of high relative importance.

Table (4): The results of analyzing the sample answers for the paragraphs of the analytical capabilities of the business environment

\begin{tabular}{|c|c|c|c|c|}
\hline No. & Dimension & $\begin{array}{c}\text { Arithmetic } \\
\text { Average }\end{array}$ & Rank & $\begin{array}{c}\text { Relative } \\
\text { Importance }\end{array}$ \\
\hline 1 & Simulation & 3.762 & 2 & High \\
\hline 2 & $\begin{array}{c}\text { Analytic quantitative } \\
\text { modeling }\end{array}$ & 3.778 & 1 & High \\
\hline \multicolumn{2}{|c|}{$\begin{array}{c}\text { Analytical capabilities of the business } \\
\text { environment }\end{array}$} & 3.756 & High \\
\hline
\end{tabular}


The results of Table (4) above indicate that the analytical capabilities of the business environment in terms of the relative importance are high, as the arithmetic mean reached (3.756). It came after (simulation) in last place with an average of (3.762) $\mathrm{K}$ and a high relative importance.

\section{Hypothesis testing}

\section{First: The Results of the First Hypothesis Test}

In order to verify the validity of the hypothesis, multiple linear regression analysis was used to find out if there was a statistically significant effect of the independent variable (Fog computing) with its dimensions (System quality, information quality, service quality, and user satisfaction) on the simulation in achieving analytical capabilities of the business environment.

Table (5): * Results of testing the effect of (Fog computing) on (Simulation)

\begin{tabular}{|c|c|c|c|c|c|c|c|c|c|c|c|c|}
\hline \multirow{2}{*}{$\begin{array}{c}\text { Depend } \\
\text { ent } \\
\text { variable }\end{array}$} & \multicolumn{4}{|c|}{ Model Summary } & \multicolumn{3}{|c|}{$\begin{array}{c}\text { ANOVA Analysis } \\
\text { of variance }\end{array}$} & \multicolumn{5}{|c|}{ Regression coefficients } \\
\hline & $\mathbf{R}$ & $\mathbf{R}^{2}$ & $\begin{array}{l}\text { Adjust } \\
\text { ed } R^{2}\end{array}$ & $\begin{array}{l}\text { Std } \\
\text { error }\end{array}$ & $\mathbf{F}$ & $\begin{array}{l}\text { Sig } \\
\text { (F) }\end{array}$ & Df & $\begin{array}{l}\text { Independent } \\
\text { variables }\end{array}$ & (B) & $\begin{array}{c}\text { Std } \\
\text { erro } \\
r\end{array}$ & $\mathbf{T}$ & $\begin{array}{l}\text { Sig } \\
\text { (T) }\end{array}$ \\
\hline \multirow{5}{*}{$\begin{array}{l}\text { Simulati } \\
\text { on }\end{array}$} & \multirow{5}{*}{$\begin{array}{c}0.87 \\
8\end{array}$} & \multirow{5}{*}{$\begin{array}{c}0.77 \\
1\end{array}$} & \multirow{5}{*}{0.768} & \multirow{5}{*}{$\begin{array}{c}0.366 \\
2\end{array}$} & \multirow{5}{*}{$\begin{array}{c}206.6 \\
23\end{array}$} & \multirow{5}{*}{$\begin{array}{l}0.0 \\
00\end{array}$} & \multirow{5}{*}{4} & System Quality & .194 & 053. & $\begin{array}{l}3.65 \\
4\end{array}$ & $\begin{array}{l}.00 \\
0 *\end{array}$ \\
\hline & & & & & & & & $\begin{array}{l}\text { Information } \\
\text { Quality }\end{array}$ & .376 & 064. & $\begin{array}{l}5.89 \\
8 \\
\end{array}$ & $\begin{array}{l}.00 \\
0 *\end{array}$ \\
\hline & & & & & & & & Service Quality & .301 & 065. & $\begin{array}{l}4.65 \\
7\end{array}$ & $\begin{array}{l}.00 \\
0 *\end{array}$ \\
\hline & & & & & & & & $\begin{array}{l}\text { User } \\
\text { satisfaction }\end{array}$ & .098 & 058. & $\begin{array}{l}1.68 \\
2 \\
\end{array}$ & $\begin{array}{l}.09 \\
4 \\
\end{array}$ \\
\hline & & & & & & & & $\begin{array}{c}\text { Regression } \\
\text { Constant }\end{array}$ & $\begin{array}{c}0.22 \\
9\end{array}$ & $\begin{array}{c}0.13 \\
2\end{array}$ & $\begin{array}{c}1.68 \\
2\end{array}$ & $\begin{array}{l}0.0 \\
83\end{array}$ \\
\hline
\end{tabular}

$\circ$ The effect is statistically significant at $(\alpha \leq 0.05)$.

It was turned out from Table (5) above that the value of $(P=206.623)$ and in terms of $(0.00)$, which is lower than $(\leq 0.05 \alpha)$. This indicates to the presence of an explanatory and significant strength to use the multiple linear regression analysis model between the independent variable (Fog computing) with its dimensions (System quality, information quality, service quality, and user satisfaction) on simulation in achieving the analytical capabilities of the business environment. In addition, the above table also indicated that the value of the correlation coefficient between the independent variable (Fog computing as a whole) with its dimensions and the dependent variable (simulation) amounted to $(0.878)$, the value of $(2 R)$ (0.771), and the value of the modified coefficient of determination (Adjusted R2) (0.768), which indicates that the independent variable (Fog computing) with its dimensions (System quality, information quality, service quality, and user satisfaction) was able to explain (76.8\%) of the changes occurring in the dependent variable (Simulation in achieving analytical capabilities), and the rest is attributed to other factors. 


\section{Second: The Results of the Second Hypothesis Test}

To test this hypothesis, multiple linear regression was analysed to see if there was a statistically significant effect of the independent variable (Fog computing) with its dimensions (System quality, information quality, service quality, and user satisfaction) on the analytical quantitative modelling in achieving analytical capabilities for the business environment.

Table (5): Results of testing the effect of (Fog computing) on (Analytical quantitative modelling)

\begin{tabular}{|c|c|c|c|c|c|c|c|c|c|c|c|c|}
\hline \multirow{2}{*}{$\begin{array}{l}\text { Dependan } \\
\text { t variable }\end{array}$} & \multicolumn{4}{|c|}{ Model Summary } & \multicolumn{3}{|c|}{$\begin{array}{l}\text { Analysis of } \\
\text { variance } \\
\text { ANOVA }\end{array}$} & \multicolumn{5}{|c|}{ Regression coefficients } \\
\hline & $\mathbf{R}$ & $\mathbf{R}^{2}$ & $\begin{array}{c}\text { Adjuste } \\
\text { d R }^{2}\end{array}$ & $\begin{array}{c}\text { Std } \\
\text { erro } \\
r\end{array}$ & $\mathbf{F}$ & $\begin{array}{l}\text { Sig } \\
\text { (F) }\end{array}$ & Df & $\begin{array}{l}\text { Independent } \\
\text { variable }\end{array}$ & B & $\begin{array}{c}\text { Std } \\
\text { erro } \\
r\end{array}$ & $\mathbf{T}$ & $\begin{array}{c}\text { Sig } \\
\mathbf{T}\end{array}$ \\
\hline \multirow{5}{*}{$\begin{array}{c}\text { Analytical } \\
\text { quantitati } \\
\text { ve } \\
\text { modelling }\end{array}$} & \multirow{5}{*}{$\begin{array}{c}0.78 \\
2\end{array}$} & \multirow{5}{*}{$\begin{array}{c}0.61 \\
1\end{array}$} & \multirow{5}{*}{0.604} & \multirow{5}{*}{$\begin{array}{c}0.46 \\
2\end{array}$} & \multirow{5}{*}{$\begin{array}{c}96.12 \\
7\end{array}$} & \multirow{5}{*}{$\begin{array}{c}0.00 \\
0\end{array}$} & \multirow{5}{*}{4} & System Quality & $\begin{array}{l}.22 \\
9\end{array}$ & .067 & $\begin{array}{l}3.42 \\
1\end{array}$ & $\begin{array}{l}.00 \\
1 *\end{array}$ \\
\hline & & & & & & & & $\begin{array}{l}\text { Information } \\
\text { Quality }\end{array}$ & $\begin{array}{l}.16 \\
3 \\
\end{array}$ & .080 & $\begin{array}{l}2.02 \\
4 \\
\end{array}$ & $\begin{array}{l}.04 \\
4^{*}\end{array}$ \\
\hline & & & & & & & & Service Quality & $\begin{array}{l}.32 \\
2\end{array}$ & .082 & $\begin{array}{l}3.95 \\
0\end{array}$ & $\begin{array}{l}.00 \\
0 *\end{array}$ \\
\hline & & & & & & & & User satisfaction & $\begin{array}{l}.11 \\
8\end{array}$ & .073 & $\begin{array}{l}1.60 \\
7\end{array}$ & $\begin{array}{l}.10 \\
9\end{array}$ \\
\hline & & & & & & & & $\begin{array}{c}\text { Regression } \\
\text { Constant }\end{array}$ & $\begin{array}{c}.57 \\
4\end{array}$ & .166 & $\begin{array}{c}3.45 \\
9\end{array}$ & $\begin{array}{l}0.0 \\
01\end{array}$ \\
\hline
\end{tabular}

* The effect is statistically significant at $(\alpha \leq 0.05)$.

Table (6) shows that the value of $(P=96.127)$ in statistical terms is $(0.00)$, which is less than $(\alpha 0.05 \alpha)$; Hence this demonstrates the explanatory and meaningful strength of using the multiple regression analysis model between (Fog computing) with its dimensions (System quality, information quality, service quality, and user satisfaction) on analytical quantitative modeling in achieving the analytical capabilities of the business environment. Hence, the value of the correlation coefficient between the independent variable (Fog computing as a whole) with its dimensions and the dependent variable (Analytical quantitative modeling) amounted to (0.782), the value of the coefficient of determination (2R) (0.611), and the value of the modified coefficient of determination (Adjusted R2) (0.604), which It indicates that the independent variable (fog computing) with its dimensions (System quality, information quality, service quality, and user satisfaction) was able to explain (60.4\%) of the changes occurring in the dependent variable (analytical quantitative modeling in achieving analytical capabilities) and the rest is attributed to other factors.

\section{Discussing and Conclusion}

The results of the study found out that there is a statistically significant effect of fog computing in its dimensions (System quality, information quality, service quality, and user satisfaction) on simulation in achieving the analytical capabilities of the business environment. This comes in line with the Karaz study (2016), which showed the presence of a statistically significant effect between the environmental factors for information management systems and the quality of information in the overall decision-making process. 
Besides, with the study of Al Rawahneh (2012), the results showed that the quality of the electronic system in all its dimensions directly affect the satisfaction of the system users in the human resources department at the Civil Service Bureau. This is also consistent with the study of lal \& bharadwaj, 2016), whose results indicated that the quality of services provided by fog computing has the greatest impact on user satisfaction and that the use of customer relationship management systems based on the use of the fog list achieves financial benefits for the organization.

The study also found out that there is an effect of system quality, information quality, and service quality on simulation. Meanwhile, there was no effect of user satisfaction on simulation which is consistent with the study of Al-Adaileh and Abu Muhdaneh (2014). Hence, the results indicated to the existence of a statistically significant effect of the quality of information on creative leadership. In addition, there is an impact of the following areas: system quality, information quality and service quality on analytical quantitative modeling. Meanwhile, there is no effect of the fourth field: user satisfaction on analytical quantitative modeling. Therefore, this is considered in the opinion of the researcher as it is due to the fact that the system is used for emergencies, and, therefore, the processes based on it are either preventive or immediate measures that the user may not directly touch through the use of the application, and, thus, have no effect. Furthermore, it may also indicate that the users' opinions are not measured by the authority, which may be referred purely for secret and military reasons which do not allow users to judge them, but, leave that to the competent authorities. Accordingly, this is in agreement with the study Hassan et al. (2017), which indicated that IT resources and external pressure greatly affect the adoption of fog computing. He disagreed with Bogataj Habjan \& Pucihar, 2017, which indicated that there was no statistically significant effect of business model factor groups on the adoption of fog computing. Hence, our recommendations for this study emerge through activating the authority's role to practice its activities in an integrated manner within cloudy or fog computing and to activate it to manage business and its uses well in light of what surprises businesses in terms of environmental surprises depending on the analysis of the internal and external environment, besides working on linking the skills and efficiency of fog computing to facilitate the work of the authority along with the quality of services provided and develop them continuously in order to increase its capabilities in facing emergency crises. In addition, make continuous improvements to business analysis systems, provide them with updated and accurate information, and create easy-to-use interactive interfaces and models that express the problems to be solved. 


\section{References}

Abdel-Karim, B. (2018), The Use of the Simulation Model to achieve Economic Enterprise Profits, Journal of North African Economics, 14 (18), Algeria.

Adnan M. A. B. (2002) Modeling and Simulation, King Saud University, Riyadh.

Agbim, K. (2013). The impact of organizational structure and leadership styles on innovation. IOSR Journal of Business and Management (IOSR-JBM), 6( 6) 56-63.

Ahmed, M. S. (2015), The Impact of Organization's Capacity on Information Quality, Journal of Economic Sciences, Sudan University of Science and Technology, 16 (1), Sudan.

Al Thani, F. B. H., \& Obeidat, A. M. (2020). The Impact of Strategic Leadership on Crisis Management. International Journal of Asian Social Science, 10(6), 307-326.

Al Yami, M., \& Schaefer, D. (2019). Fog Computing as a Complementary Approach to Cloud Computing. International Conference on Computer and Information Sciences (ICCIS).doi:10.1109/ICCISci.2019.8716402

Al-Adayleh, R., \& Abu Samhadana, M. (2014) The quality of information and its impact on creative leadership from the viewpoint of the employees of the Jordan Islamic Bank for Investment and Finance in the governorates of the southern region. The Jordanian Journal of Business Administration, 10 (3) 404-425.

Al-Fadl, M. A. (2006), The Quantitative Approach in Business Administration, 1st Edition, AlWarraq for Publishing and Distribution, Amman, Jordan.

Al-Hiti, K. A.-Rahim, M. (2000). Quantitative Methods, an Introduction to Administrative Decision Making, 1st Edition, Al-Hamid House for Publishing and Distribution, Amman, Jordan.

Aljawarneh, N. M., Sokiyna, M., Obeidat, A. M., Alomari, K. A. K., Alradaideh, A. T., \& Alomari, Z. S. (2020). The Role of CRM fog computing on innovation and customer service quality: An empirical study

Al-Mahamid, S. M. (2012), The Impact of Perceived Reliability of Electronic Business Systems on User Satisfaction, A field study in Jordan Telecom Company, Journal of Administrative Sciences Studies, 39 (2).

Alomari, K. A. K. (2020). Linking between E-government and Money Laundering: The Mediating Role of Compliance Unit. INTERNATIONAL JOURNAL OF ACADEMIC RESEARCH IN BUSINESS AND SOCIAL SCIENCES, 10(2).

Al-Omari, Z., Alomari, K., \& Aljawarneh, N. (2020). The role of empowerment in improving internal process, customer satisfaction, learning and growth. Management Science Letters, 10(4), 841-848.

Al-Qudah, S., Obeidat, A. M., \& Shrouf, H. (2020). The impact of strategic human resources planning on the organizational performance of public shareholding companies in Jordan. Problems and Perspectives in Management, 18(1), 219.

Al-Rawahneh, A. O. (2013) "The Impact of the Quality of E-HRM Systems on the Efficiency of Employee Performance: A Case Study in the Jordan Telecom / Orange Group", Master Thesis, Jordan University, Middle East Amman, Jordan.

Barik, R. K., Lenka, R. K., Dubey, H., \& Mankodiya, K. (2018). TCloud: Cloud SDI Model for Tourism Information Infrastructure Management. In GIS Applications in the Tourism and Hospitality Industry (pp. 116-144). Hershey, PA: IGI Global. doi:10.4018/978-15225-5088-4.ch006.

Barik, R., Dubey, H., Sasane, S., Misra, C., Constant, N., \& Mankodiya, K. (2017b). Fog 2 fog: augmenting scalability in fog computing for health GIS systems. In Proceedings of the Second IEEE/ACM International Conference on Connected Health: Applications, 
Systems and Engineering Technologies (pp. 241-242). IEEE Press. doi:10.1109/CHASE.2017.83.

Bilal, M. I. (2005). Operations Research: Using Quantitative Methods in Decision-Making, New University House, Alexandria, Egypt.

Chin, N. (2012). Critical success factors of location-based services. Master Thesis, University of Nebraska, USA.

Conklin, M., Powaga, K., \& Lipovetsky, S.(2004),"Customer Satisfaction identification of key drivers" European Journal of Operational Research ,15(4) 819-827.

Dastjerdi, A. V., Gupta, H., Calheiros, R. N., Ghosh, S. K., \& Buyya, R. (2016). Fog computing: Principles, architectures, and applications.

Duran-Arenas, L., Rivero, C. C., Canton S. F. (1998) The Development of a Quality Information System: A Case Study of Mexico. Health Policy and Planning; 13(4) P P 446-58.

Darwish, S., \& Abdeldayem, M. M. (2019). Risk Management and Business Ethics: Relations and Impacts in the GCC. International Journal of Civil Engineering and Technology, 10(10), 489-504.

Fiduccia, A., Gugliermetti, F., Pagliaro, F., Mattoni, B., Nardecchia, F., \& Canu, C. (2016). Web - Based Spatial Decision Support Systems to Monitor and Manage Coastal Environments. In Proceedings of the 18th Italian National Conference on Photonic Technologies. Academic Press. doi:10.1049/cp.2016.0920

Frost, F. A. (2003).The use of Strategic tools by small and medium sized enterprises: An Australian Study. Start change12:49-62.-Ganzha, L. Maciaszek, \& M. Paprzycki (Eds.), Proceedings of the 2014 Federated Conference on Computer Science and Information Systems. Pp1103-1110.

Habjan, K. B., \& Pucihar, A. (2017). The importance of business model factors for cloud computing adoption: Role of previous experiences. Organizacija, 50(3), 255-272.

Haider, A. H. (2006). The Impact of Technology on the Banking Industry in Sudan, Central Bank of Sudan Research Series.

Hall, R. (1993). A Frame work linking intangible resources and capabilities to sustainable competitive advantage, Strategic Management Journal ,Vol.14:607-618.

Hamdan, F. K. (2010), Operations Research with Computer Applications, Wael Publishing House, Amman, Jordan.

Hassan, M. M. (2008), Management Information Systems, University House, Ibrahimia, Raml Alexandria.

Irtaimeh, H. J., Obeidat, A., \& Khaddam, A. (2016). Strategic Role of Dashboard Application in Enhancing Crisis Management Capabilities in Organizations Field Study on Jordanian Cellular Companies. International Journal of Management Sciences and Business Research.5(10)50-59

Javadzadeh, G., \& Rahmani, A. M. (2020). Fog computing applications in smart cities: A systematic survey. Wireless Networks, 26(2), 1433-1457.

Karaz, M. (2016), The environmental factors of education information management systems and their impact on the quality of information used in decision-making - An applied study on EMIS in UNRWA schools in the Gaza Strip, unpublished master's thesis. Islamic University of Gaza.

Kotler, P., \& Keller, K. (2012),"Marketing Management", 14th Edition, Englewood Cliffs NJ, Prentice Hall International.

Lal, P., \& Bharadwaj, S. S. (2016). Understanding the impact of cloud-based services adoption on organizational flexibility. Journal of Enterprise Information Management. 
Latifi, M., \& Shooshtarian, Z. (2014). The effects of organizational structure on organizational trust and effectiveness. Polish Journal of Management Studies, 10( 2) 73-84.

Mahafzah, A. G., Aljawarneh, N. M., Alomari, K. A. K., Altahat, S., \& Alomari, Z. S. (2020). Impact of customer relationship management on food and beverage service quality: The mediating role of employees satisfaction. Humanities \& Social Sciences Reviews, 8(2), 222-230.

Mahfodh, A. B. S. B., \& Obeidat, A. M. (2020). Knowledge Sharing Tools and their Impact on Enhancing Organizational Performance. International Journal of Academic Research in Business and Social Sciences. 10(9), 91-112.

Malkawi, N., Obeidat, A. M., \& Halasa, A. (2017). Achieving Performance Excellence through Cloud Computing Atmosphere-Applied Study at Zain Telecommunications CompanyJordan. International Review of Management and Business Research, 6(1), 229-243.

Najm, A. N. (2001). Management of Modern Operations, Systems, Methods and Trends, Institute of Public Administration, Saudi Arabia.

Navas, J. E. (2007), Explaining and measuring success in new business: The effect of technological capabilities on firm results, Technovation,27( 1)130-46.

Obeidat, A. (2019). IT Adaption with Knowledge Conversion Process (SECI)?. Management Science Letters, 9(13), 2241-2252.

Obeidat, A. M., \& Otibi, G. A. (2015). The impact of knowledge sharing tools on levels of organizational learning (Field Study on Jordanian Commercial Banks). Australian Journal of Basic and Applied Sciences, 9(5), 253-267.

Paul, J., \& Muthumani, S. (2015). A Study on channelizing the brand with CRM applications in Indian banking services. International Journal of Applied Engineering Research, 10, 7091-7097.

Ramachandran, A., \& Chidambaram, V. (2012). A review of customer satisfaction towards service quality of banking sector. Periodica Polytechnica. Social and Management Sciences, 20( 2) 71.

Saffar, N., \& Obeidat, A. (2020). The effect of total quality management practices on employee performance: The moderating role of knowledge sharing. Management Science Letters, 10(1), 77-90.

Shana, Z., \& Abulibdeh, E. (2017). Cloud computing issues for higher education: theory of acceptance model. International Journal of Emerging Technologies in Learning (iJET), 12(11), 168-184.

Shrouf, H., Al-Qudah, S., Khawaldeh, K., Obeidat, A., \& Rawashdeh, A. (2020). A study on relationship between human resources and strategic performance: The mediating role of productivity. Management Science Letters, 10(13), 3189-3196.

Singhania, M., Gupta, A., Madhavaiah, C., Bashir, I., Shafi, S. I., Siddiqui, A. A., \& Kaur, P. (2012). Management Case. The Journal of Business, 16(3).

Stanoevska, K., Wozniak, T., \& Ristol, S. (Eds.). (2009). Grid and cloud computing: a business perspective on technology and applications. Springer Science \& Business Media.

Tassabehji, R., \& Isherwood, A. (2014), Management Use of strategic Tools for innovating During Turbulent Times .John Wiley \& Sons . Ltd . start . change 23:63-80.

Tran, Q., \& Tian, Y. (2013). Organizational Structure: Influencing Factors and Impact on a Firm. American Journal of Industrial and Business Management, 3, 229-236.

Van Quyet, T., Vinh, N., \& Chang, T. (2015). Service quality effects on customer satisfaction in banking industry. International Journal of u-and e-Service, Science and Technology, 8 (8)199-206. 
Vaquero, L. M., Rodero-Merino, L. (2014): Finding your way in the fog: Towards a comprehensive definition of fog computing. ACM SIGCOMM CCR 44 .

Voloshina, V. (2014).The Strategic Management Tools for Higher Education Institutions. EKOHOMIKA, 2 (155).

Wright, R. P., Paroutis, S. E., \& Blettner, D. P. (2013). How Useful Are The Strategic Tools We Teach in Businesses School? Journal Management Studies 50:1. 